\title{
SILICATE NICKEL AND ITS APPLICATION TO THE EXPLORATION OF NICKEL ORES
}

\begin{abstract}
T. A. HäKLI
Ḧ̈KLI, T. A. 1971: Silicate nickel and its application to the exploration of nickel ores. Bull. Geol. Soc. Finland 43, 247-263.

The paper is based on the analytical data obtained from c. 10000 Finnish mafic-ultramafic samples collected by the Exploration Department of the Outokumpu Co. in terms of an extensive exploration programme for nickel ores. The average abundances of nickel in mafic silicates of the rocks of peridotite-quartzdiorite series are given, as well as the frequency distributions of nickel abundances in these minerals for each rock type. The nickel partition coefficients of the mineral pairs: olivine-augite, olivine-orthopyroxene, olivineamphibole, amphibole-augite, amphibole-orthopyroxene and orthopyroxeneaugite are reported for various rock types with the emphasis on the model temperature estimation and its explorational application. The nickel percentage in the sulphide phase as against the rock types is examined and the partition of nickel between the mafic silicates and the coexisting sulphide phase revised. It is shown that sulphides tend to extract nickel from silicates, which fact is tentatively attributed either to autosulphurisation or sulphurisation due to external sulphur. The distribution patterns of the abundances of silicate nickel in mafic intrusives are discussed and it is concluded that the intrusives can be divided into two groups accordingly. Group I comprises the zoned complexes with high nickel values in the centre and Group II the stratiform or related bodies. The areal distribution of the locations of the samples with a high nickel percentage in the sulphide phase or of those with high suphide nickel are given and their bearing on decision-making with regard to strategic nickel prospecting discussed.
\end{abstract}

T. A. Häkli, Outokumpu Company, P. O. Box 27, 02101 Tapiola, Finland.

\section{Introduction}

In 1960 a programme was commenced in the Geological Laboratory of the Outokumpu Company in the frame of which efforts have been made to explore various aspects pertinent to the geochemistry of nickel in the mafic-ultramafic rocks of Finland. Special emphasis has been laid on the distribution of nickel within basic bodies as well as the spread of nickel-rich intrusives throughout the country. One of the key targets has also been the relationship between the abundance of nickel in primary mafic silicates, such as olivines, orthopyroxenes, augites and amphiboles on the one hand, and the coexisting sulphide phase on the other. Some of the findings 
of the programme have been reported previously (Häkli, 1963, 1968, 1970).

The programme, aims at two goals. First, to serve strategic exploration by providing the management of exploration with reliable information concerning the areal distribution of mafic-ultramafic rocks the geochemical properties of which suggest the possible presence of sulphide nickel ores. Second, to aid tactic exploration, i.e. the field geologists, by furnishing data pertinent to the geochemistry, differentiation and crystallisation history of individual mafic intrusives and thus delineating the location of the critical parts of the bodies at which explorational activities in conjunction with other methods could be directed.

Systematic sampling of the Finnish maficultramafic rocks began in 1963 and, at the time of writing, the specimens collected and analysed outnumber 10.000 . The data accumulated are too vast and, to some extend, too local in character to warrant a through presentation. Instead, only those aspects are dealt with in the present paper which the author believes are of explorational importance or contribute to the geochemistry of nickel in upper lithosphere in general. Irrespective of the fact that the nickel programme has already been in operation for a decade, the time has still been too short to allow an objective evaluation of the methods developed herein. Of necessity, the ideas and conclusions pertinent to the explorational applications presented in this paper are subject to the author's personal bias and may thus need some future rectifications.

\section{Methods}

The sampling was carried out on the basis of the geological maps published by the geological survey of Finland or produced by the geological staff of the Outokumpu Co. in the course of areal geological studies. Rocks ranging from quartz diorite to dunite were accepted and samples from each individual intrusive were collected in numbers proportional to its size.
Exceptions were those intrusives which were submitted to a tactical study and thus required a denser sampling grid. The samples were taken according to their representativeness without giving any preference to the possible sulphiderich portions of the rocks.

Polished thin sections were made for each sample. The sections were studied microscopically after which they were coated with aluminium under high vacuum. Subsequently, olivine, orthopyroxene, augite and amphibole, if present, were analysed for nickel by means of an electron microprobe (Geoscan) following the procedure described by Häkli (1967). Three spot analyses, each from a separate grain, were done for every mafic mineral species present in the sections. The averages of these tree determinations were taken as the representative values for the abundance of nickel in the minerals in question.

Samples with an abundance of sulphur exceeding $0.1 \%$ were employed for the determination of the composition of the sulphide phase. To avoid the error induced by the silicate nickel from olivine and micas the samples were not leached in $\mathrm{HNO}_{3}$ in the usual way but, instead, the sulphides were decomposed with bromine water. For this purpose, $5 \mathrm{~g}$ of the powdered samples were weighed into $100 \mathrm{ml}$ volumetric flasks and $10 \mathrm{ml}$ dilluted bromine water added. The mixture was kept at $70-80 \mathrm{C}^{\circ}$ for about 15 minutes after which the excees of bromine was expelled by bringing the solution to the boil. The volumetric flasks were then filled with water and the insoluble material removed with a centrifuge. The solutions were subsequently analysed for $\mathrm{Ni}, \mathrm{Co}$ and $\mathrm{Cu}$ with Perkin-Elmer 303 AAS equipment. Sulphur was determined by a Philips vacuum X-ray spectrometer provided with a Cr-tube and a penta-erythritol crystal.

The abundance of nickel in the sulphide phase of some peridoties and olivine gabbros with a low sulphur percentage (less than $0.1 \%$ ) was determined by electron microprobe. The procedure was as follows: using the appropriate 
magnification the sample holder was moved into such a position that a sulphide grain was located in the middle of the screen of the display tube. One spectrometer was set at the angle of the $\mathrm{K} \alpha$-line for sulphur and the other at the angle of the $\mathrm{K} \alpha$-line for nickel. The number of pulses from both channels were counted simultaneously by scaler units during one scan of the electron beam over the sulphide grain. The pre-set count was set at $10^{8}$ and the counting performed manually. The procedure was repeated for a sufficient number of sulphide grains without resetting the scaler units. After the completion of the measurements the ratio of the accumulated $\mathrm{Ni}_{K \alpha}$ and $\mathrm{S}_{K_{\alpha}}$ pulses was computed. In a similar manner the corresponding ratio was determined for a pentlandite standard. Since the sulphur percentage in the sulphide phase of the mafic-ultramafic rocks is approximately constant and nearly the same as that of pentlandite, it follows that

$$
\mathrm{S}^{N i}=\frac{\mathrm{I}_{S a}^{N i} \cdot \mathrm{I}_{S t}^{N i} \cdot \mathrm{P}}{\mathrm{I}_{S a}^{S} \cdot \mathrm{I}_{s t}^{N i}}
$$

where $\mathrm{S}^{N i}=$ nickel percentage in the sulphide phase, $\mathrm{I}_{S a}^{N i}$ and $\mathrm{I}_{S a}^{S}=$ number of pulses of $\mathrm{Ni}_{K_{\alpha}}$ - and $\mathrm{S}_{K a}$-lines from the sample, $\mathrm{I}_{S t}^{N i}$ and $\mathrm{I}_{S t}^{S}$ number of pulses of the same lines from the standard, and $\mathrm{P}=\mathrm{Ni}$-percentage of the standard. This formula gives a reliable estimate provided that the grains to be analyse are not too small, i.e. that the time the beam scans the sulphide grains is not shorter than the time it sweeps the silicate grains. Should the opposite hold true then

$$
\mathrm{S}^{N i}=\frac{\left[\mathrm{M}^{N i}-(\mathrm{A}-\mathrm{B}) \mathrm{I}_{S i}^{N i}\right] \cdot \mathrm{I}_{S t}^{S} \cdot \mathrm{P}}{\mathrm{B} \cdot \mathrm{I}_{S i}^{S} \cdot \mathrm{I}_{S t}^{N i}}
$$

where $\mathrm{M}_{N i}$ and $\mathrm{M}_{S}$ are the numbers of the $\mathrm{Ni}_{K \alpha}$ and $\mathrm{S}_{K \alpha}$ pulses obtained from the sample during time $\mathrm{A}, \mathrm{B}$ is the time, in seconds, during which the beam scanned the sulphide grains, $\mathrm{I}_{S}^{S}$ is the intensity of the $S_{K_{a}}$-line from the sulphide grains (peak + background), $I_{S i}^{S}$ the intensity of the $\mathrm{S}_{K_{a}}$-line from the silicates and $\mathrm{I}_{S i}^{N i}$ the intensity of the $\mathrm{Ni}_{K_{\alpha}}$-line from the silicates. Time B is obviously

$$
\mathrm{B}=\frac{\mathrm{M}_{S}-\mathrm{A} \cdot \mathrm{I}_{S i}^{S}}{\mathrm{I}_{S}^{S}-\mathrm{I}_{S i}^{S}}
$$

The data processing was carried out in the computer centre of the Outokumpu Co. by an IBM $360 / 40$ computer.

\section{Nickel in mafic silicates}

It is a well-known fact that the abundance of nickel in mafic cumulus crystals strongly decreases with the progress of the magmatic differentiation (Wilson, 1953; Häkli, 1968). The data produced by the present study support the earlier views in this respect. In the differentiation series dunite-quartz diorite the abundances of nickel in mafic silicates decrease almost exponentially if examined as a function of silica per cent (Fig. 1.). The samples collected for the nickel programme show that the abundance of nickel in olivines of Finnish peridotites averages $1330 \mathrm{ppm}$. The mean

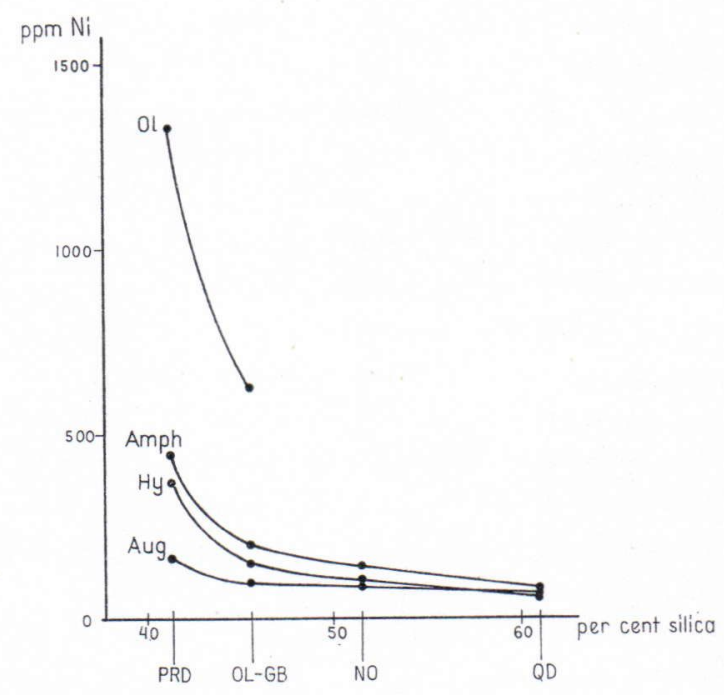

FIG. 1. The average nickel abundances in olivines, amphiboles, hypersthenes and augites as against the silica per cent. Based essentially on the same analytical data as the graphs in Figs. 2-4. 
values for orthopyroxenes, augites and amphiboles of this rock type are 370 ppm, 164 ppm and 445 ppm, respectively. In the olivine gabbros the mafic silicates contain noticeably less nickel than in peridotites. The average value for olivines is $620 \mathrm{ppm}$, for orthopyroxene $150 \mathrm{ppm}$, for augite $100 \mathrm{ppm}$ and for amphibole $200 \mathrm{ppm}$. In pyroxene gabbros the depletion of nickel has proceeded still further, the average values for orthopyroxenes, augites and amphiboles being $105 \mathrm{ppm}, 90 \mathrm{ppm}$ and $140 \mathrm{ppm}$, respectively. The silicates of quartz-diorites contain even less nickel than those of gabbros. Orthopyroxenes, augites and amphiboles average $60 \mathrm{ppm}, 65 \mathrm{ppm}$ and $80 \mathrm{ppm} \mathrm{Ni}$, respectively.

The rations of the mean nickel contents in the silicates vary somewhat as the differentiation preceeds. This is especially conspicuous for the orthopyroxene and augite. In the range of peridotite - pyroxene gabbro, orthopyroxenes invariably contain more nickel than the coexisting augites. In quartz-diorites, however, the opposite often holds true and to such an extent that the average nickel content in augite exceeds that in orthopyroxene. This fact, which will be dealt with again in connection with the partition coefficients, has been attributed by the present author (Häkli and Wright, 1967; Häkli 1968) to the effect of the crystallisation temperature. Its significance to the explorational applications will be discussed later in this paper.

The cumulative frequency distributions of nickel in the mafic silicates of peridotites and olivine gabbros approximate normal distribution (Fig. 2.). In practice, the nickel content in the olivine of peridotites ranges from $100 \mathrm{ppm}$ to 3200 ppm, even though values lower than 100 ppm have occasionally been encountered. The olivines with exceptionally low nickel abundances come from the iron-rich peridotites which often are small in size and frequently in association with granodiorite bodies representing their ultramafic fasies. In places the relationship between these peridotites and acid plutonic rocks, however, is obscure as the former occur as lenses

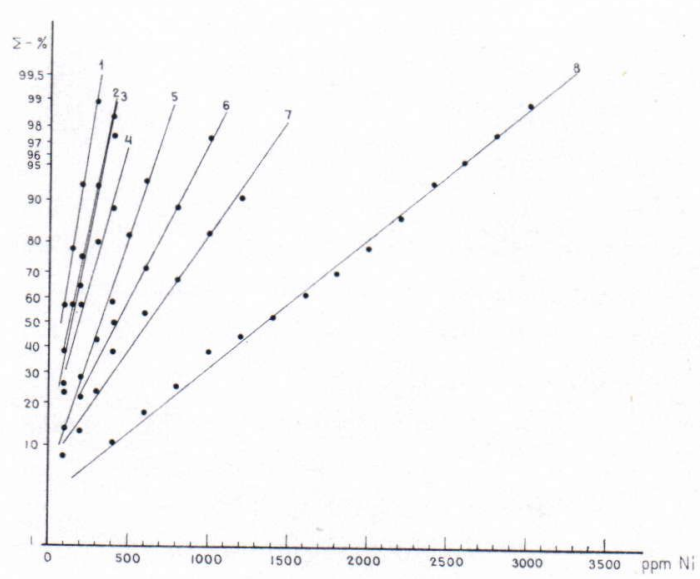

FIG. 2. The cumulative frequency distributions of the nickel abundances in the mafic minerals of Finnish peridotites and olivine gabbros. 1 augites of olivine gabbros (95), 2 hypersthenes of olivine gabbros (128), 3 augites of peridotites (153), 4 amphiboles of olivine gabbros (35), 5 hypersthenes of peridotites (150), 6 amphiboles of peridotites (377), 7 olivines of olivine gabbros (124) and 8 olivines of peridotites (432). The numbers in the parentheses refer to the number of samples analysed.

embedded in mica schists without exhibiting any direct connection with other plutonic rocks. The predominant nickel-rich olivines evidently derrive from magmas of basaltic or related composition. As the highest nickel abundances seem to converge towards a limit value of about $4000 \mathrm{ppm}$ it may be concluded that the abundance of nickel in olivine in the upper mantle is of the same order of magnitude. A similar tendency is also evident in the data of nickel abundances in olivines reported by Simkin and Smith (1970). The nickel content of the olivines in the olivine gabbros ranges from $50 \mathrm{ppm}$ to $1800 \mathrm{ppm}$. Values as low as $10-20 \mathrm{ppm}$ have been met with in a few cases. On the other hand, the highest abundance of nickel recorded so far is $3700 \mathrm{ppm}$. As Fig. 2 illustrates, the cumulative frequency distributions of the nickel in the orthopyroxenes of olivine gabbros and the nickel in the augites of peridotites are identical within the limits of analytical error.

The frequency distribution of the nickel abundaces in the mafic silicates of peridotites 


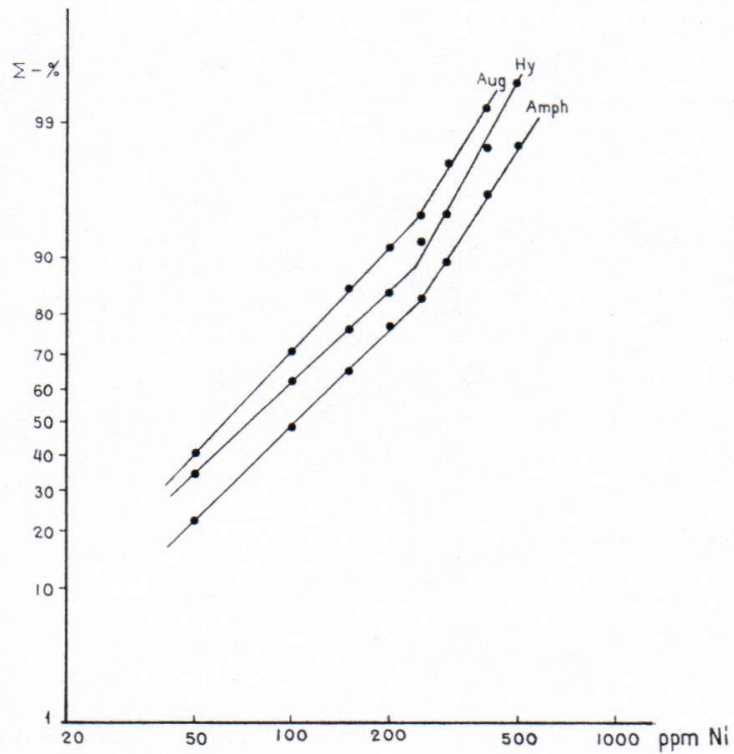

FIG. 3. The cumulative frequency distributions of the nickel abundances in the augites, hypersthenes and amphiboles of Finnish pyroxene gabbros. Based on 555 augite, 713 hypersthene and 651 amphibole analyses.

and olivine gabbros, approaches that of the normal Gaussian distribution. However, as the differentiation proceeds, the type of the frequency distribution changes towards that of lognormal or gamma distribution (Oertel, 1969) as is illustrated in Fig. 3. The nickel content in amphiboles is higher than that in orthopyroxene, which in turn, invariably exceeds the abundance of nickel in the coexisting augite. The lognormal type of the frequency distribution also characterises the abundance of nickel in amphiboles of hornblende gabbros, diorites and quartz-diorites (Fig. 4). The distribution for hornblende gabbros exhibits slightly bimodal or gamma features, whereas for diorites and quartzdiorites the distribution is very nearly lognormal.

The present author has reported some values for the nickel partition coefficients in his previous paper (Häkli, 1963). In Table 1 there is a list of new values for the partition coefficients of the mineral pairs: olivine-augite, olivine-orthopyroxene, olivine-amphibole, amphibole-augite, amphibole-orthopyroxene and orthopyroxene-au-

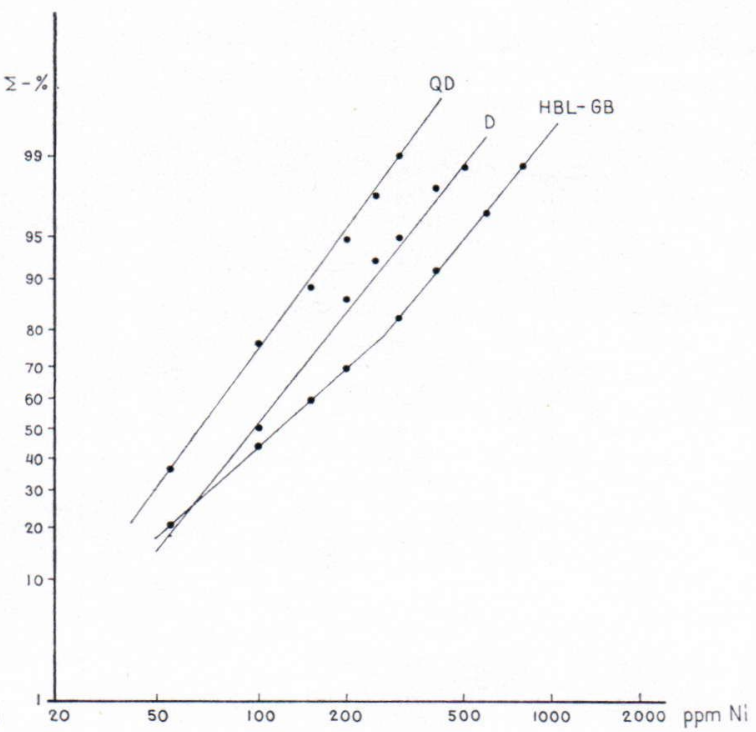

Frg. 4. The cumulative frequency distributions of the nickel abundances in amphiboles. $\mathrm{QD}=$ quartz diorite (855), $\mathrm{D}=$ diorite (158) and HBL-GB = hornblende gabbro (1888). The numbers in the parentheses refer to the number of the samples analysed.

gite. The data are listed in accordance with the rock types. The examination of the values reveals that positive and highly significant correlations exist between the abundances of nickel in coexisting silicates and that there is a general tendency for the partition coeffients to decrease towards the lower temperature differentiates. The present author has discussed this phenomenon previously (Häkli and Wright, 1967; Häkli, 1968) and attributed it to the effect of the crystallisation temperature. The partition of nickel between coexisting olivine and augite has been employed tentatively for the evaluation of model crystallisation temperatures of some basic rocks of appropriate composition (Häkli, 1968; Evans, 1969). The feasibility of this method implies chemical equilibrium between the mineral pairs involved. Depending on the size and cooling history of an intrusive, the range of the observed model temperatures vary considerably. If the volume of the magma is small implying a rapid cooling then the dispersion in the model temperatures remains small. For the large intrusives the cooling rate 
TABle 1.

Partition coefficients for nickel between the mineral pairs of olivine-augite, olivine-hypersthene, olivine-amphibole, amphibole-augite, amphibole-hypersthene and hypersthene-augite.

\begin{tabular}{|c|c|c|c|c|c|}
\hline Partition & Rock type & $\mathrm{K}$ & $\mathrm{SD}$ & $\mathrm{R}$ & $\mathrm{N}$ \\
\hline$\underset{\Downarrow}{\mathrm{OlN}^{N i} / \operatorname{AugN}^{N i}}$ & $\begin{array}{l}\text { Peridotite } \ldots \ldots \ldots \ldots \ldots \ldots \ldots \\
\text { Olivine gabbro } \ldots \ldots \ldots \ldots \ldots \ldots\end{array}$ & $\begin{array}{l}5.88 \\
5.15\end{array}$ & $\begin{array}{l}2.11 \\
1.96 \\
\end{array}$ & $\begin{array}{l}0.712 \\
0.893 \\
\end{array}$ & $\begin{array}{r}133 \\
68 \\
\end{array}$ \\
\hline$\underset{\Perp}{\mathrm{OlNi} / \mathrm{Hy}^{N i}}$ & 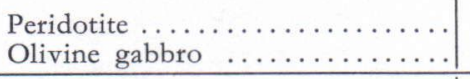 & $\begin{array}{l}4.19 \\
4.08 \\
\end{array}$ & $\begin{array}{l}1.14 \\
1.39 \\
\end{array}$ & $\begin{array}{l}0.867 \\
0.918 \\
\end{array}$ & $\begin{array}{l}133 \\
100 \\
\end{array}$ \\
\hline$\underset{\|}{\mathrm{O}{ }^{N i} / \mathrm{Amph}^{N i}}$ & $\begin{array}{l}\text { Peridotite } \ldots \ldots \ldots \ldots \ldots \ldots \ldots \ldots \\
\text { Olivine gabbro } \ldots \ldots \ldots \ldots \ldots \ldots\end{array}$ & $\begin{array}{l}3.23 \\
3.15\end{array}$ & $\begin{array}{l}1.25 \\
0.93\end{array}$ & $\begin{array}{l}0.844 \\
0.941\end{array}$ & $\begin{array}{r}275 \\
28\end{array}$ \\
\hline $\begin{array}{c}\text { AmphNi/AugNi } \\
\text { » } \\
» \\
" \\
\end{array}$ & $\begin{array}{l}\text { Peridotite } \ldots \ldots \ldots \ldots \ldots \ldots \ldots \ldots \\
\text { Olivine gabbro } \ldots \ldots \ldots \ldots \ldots \ldots \ldots \\
\text { Pyroxene gabbro } \ldots \ldots \ldots \ldots \ldots \ldots \ldots \\
\text { Diorite } \ldots \ldots \ldots \ldots \ldots \ldots \ldots \ldots\end{array}$ & $\begin{array}{l}2.12 \\
2.11 \\
2.07 \\
1.47\end{array}$ & $\begin{array}{l}0.65 \\
0.55 \\
2.99 \\
0.76\end{array}$ & $\begin{array}{l}0.855 \\
0.972 \\
0.863 \\
0.734\end{array}$ & $\begin{array}{r}88 \\
19 \\
339 \\
25 \\
\end{array}$ \\
\hline $\begin{array}{c}\mathrm{Amph} N i / \mathrm{Ni}^{N i} \\
" \\
" \\
» \\
\end{array}$ & $\begin{array}{l}\text { Peridotite } \ldots \ldots \ldots \ldots \ldots \ldots \ldots \\
\text { Olivine gabbro } \ldots \ldots \ldots \ldots \ldots \ldots \\
\text { Pyroxene gabbro } \ldots \ldots \ldots \ldots \ldots \\
\text { Diorite } \ldots \ldots \ldots \ldots \ldots \ldots \ldots\end{array}$ & $\begin{array}{l}1.46 \\
1.47 \\
1.33 \\
1.36 \\
\end{array}$ & $\begin{array}{l}0.42 \\
0.36 \\
0.51 \\
0.88 \\
\end{array}$ & $\begin{array}{l}0.763 \\
0.925 \\
0.908 \\
0.888 \\
\end{array}$ & $\begin{array}{r}89 \\
28 \\
322 \\
20 \\
\end{array}$ \\
\hline $\begin{array}{c}\mathrm{Hy}^{N i} / \operatorname{Aug}^{N i} \\
" \\
" \\
"\end{array}$ & $\begin{array}{l}\text { Peridotite } \ldots \ldots \ldots \ldots \ldots \ldots \ldots \ldots \\
\text { Olivine gabbro } \ldots \ldots \ldots \ldots \ldots \ldots \\
\text { Pyroxene gabbro } \ldots \ldots \ldots \ldots \ldots \ldots \\
\text { Diorite } \ldots \ldots \ldots \ldots \ldots \ldots \ldots\end{array}$ & $\begin{array}{l}1.46 \\
1.39 \\
1.33 \\
1.04\end{array}$ & $\begin{array}{l}0.31 \\
0.33 \\
0.51 \\
0.69\end{array}$ & $\begin{array}{l}0.939 \\
0.939 \\
0.948 \\
0.792\end{array}$ & $\begin{array}{r}37 \\
67 \\
322 \\
13\end{array}$ \\
\hline
\end{tabular}

$\mathrm{K}=$ Mean partition coefficient

$\mathrm{SD}=$ Standard deviation

$\mathrm{R}=$ Coefficient of correlation

$\mathrm{N}=$ Number of determinations

is obviously so slow that appreciable amounts of cumulus crystals have time to grow large enough to sink down to the bottom of the magma chamber at a practically constant temperature. On the bottom they are buried under the accumulation of subsequently forming crystals thus being isolated from the melt and hindered from reacting with it. Since the volume of the intercumulus liquid which occupies the interstices between the cumulus crystals is likely small compared with that of cumulus crystals then the reaction between solid and liquid phases can only take place to a limited degree. Instead of being materially re-equilibrated at lower temperature the cumulus crystals retain almost their original nickel partition. Evidently this mechanism is responsible for the fairly large variation in the values of the $\mathrm{Ol}^{N i} / \mathrm{Aug}^{\mathrm{Ni}}$ partition coef- ficient which is observed in some mafic intrusives.

Fig. 5 illustrates the dependence of the abundance of nickel in olivine on the $\mathrm{Ol}^{\mathrm{Ni}} / \mathrm{Aug}^{\mathrm{Ni}}$ model temperature in some mafic intrusives in Finland. Due to the assimilation or the presence of appreciable amounts of sulphides or some other factors the points do not invariably fall on a smooth curve but exhibit considerable dispersion, especially if the intrusive is small in size. Only large differentiated intrusives seem to show functional dependence of the types illustrated in Fig. 5. The curves in this figure represent five mafic bodies, of which the intrusives of Parikkala (Häkli, 1968, 1970), Joutsenmäki-Tolvaniemi I (Gaál and Rauhamäki, 1971; Hackman, 1933), Kangasniemi (Frosterus, 1902) and Myhinkoski, in Rautalampi show fairly 


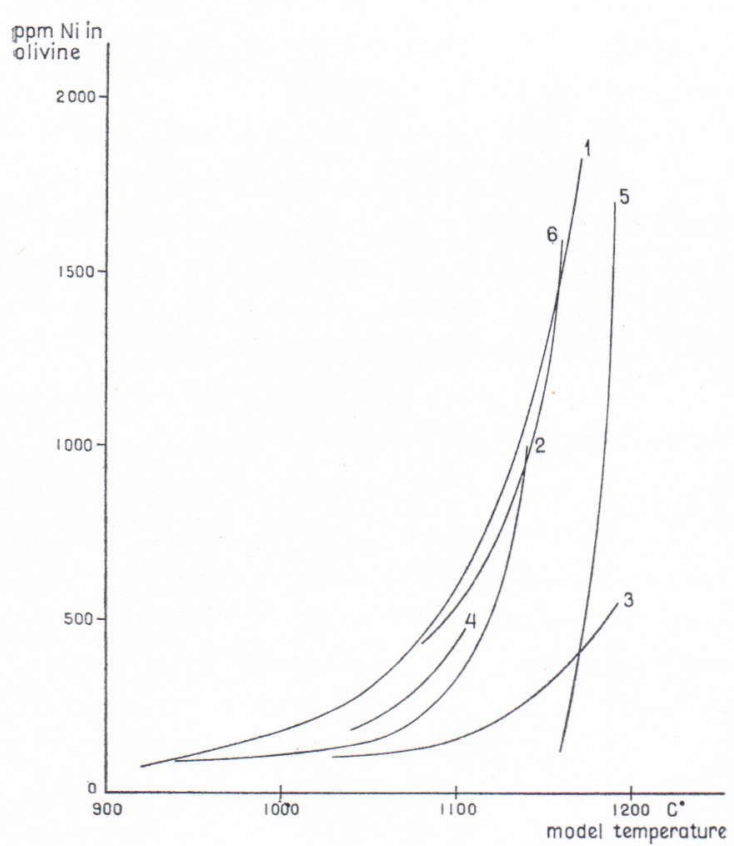

FIG. 5. The abundance of nickel in olivine as against the $\mathrm{OlNi} / \mathrm{Aug}^{N i}$ model crystallisation temperature in some Finnish mafic intrusives. 1 Parikkala, 2 Joutsenmäki-Tolvaniemi I, 3 Joutsenmäki-Tolvaniemi II,

4 Kangasniemi, 5 Kevitsa and 6 Myhinkoski, Rautalampi.

similar cooling histories. In addition, the curves also suggest that the abundances of nickel in the magmas of these intrusives were nearly the same. From the point of view of explorational application it is important to note that the intrusives of Kangasniemi and Joutsenmäki-Tolvaniemi I lack the high-temperature differentiates on their present surface. However, the shapes of the curves suggest that these intrusives may include nickel-rich high-temperature rocks in their hidden parts. This implies that for the explorational evaluation of mafic intrusives it is essential to consider the model temperatures and compare the abundances of nickel in silicates or in sulphide phases only between those samples whose model temperatures are at least approximately equal. Otherwise conclusions may be reached which will turn out later to be wrong.
The Joutsenmäki-Tolvaniemi intrusive also offers an example of a massif which was produced by two intrusions of magmas with different abundances of nickel in each. Curve 2 obviously represents the original composition of the magma, whereas curve 3, which extends to the high-temperature region, illustrates either an entirely different parent magma or the original magma, whose composition was altered through assimilation. The curve for the Kevitsa intrusive (Mikkola, 1941) differs clearly from the others. It is very steep and occurs entirely in the hightemperature range, which indicates that the intrusive was equilibrated at an almost constant temperature. This may be attributed to the penetration and crystallisation of the magma in the superficial parts of the bedrock. Further evidence for that is provided by the fact that quenched lava has been found near the northern contact of the Kevitsa intrusive. Its composition refers to a comagmatic relationship with the Kevitsa massif. The lava contains about 90 percent partly devitrified glass, in which phenocrysts of olivine, augite, orthopyroxene and plagioclase are embedded.

\section{Partition of nickel between mafic silicates and the coexisting sulphide phase}

As shown by the present author (Häkli, 1963), a significant positive correlation exists between the nickel content of primary mafic silicates and the coexisting sulphide phase in mafic-ultramafic rocks with abundant nickel-bearing sulphides.

Whether or not a similar relationship also holds true in rocks with a low sulphur content is of importance to the explorational interpretation of the analytical data concerning the abundance of nickel in silicates. The problem was studied by analysing the sulphide phases of those samples collected for the Ni-programme which contained sulphur in excess of $0.1 \%$. To avoid contamination by silicate nickel the sulphides were dissolved in bromine water and analysed by AAS in the manner described in the chapter on 
methods. On the basis of the analytical data, the nickel percentages in the sulphide phases were computed by assuming the sulphide phase to contain $37 \%$ sulphur.

Like the abundance of nickel in mafic silicates the nickel percentage in the sulphide phase decreases parallel to the progress of the crystallisation differentiation and, consequently to the increase in the silica percentage of the host rock. This is illustrated in Fig. 6 which depicts the average nickel percentage of the sulphide phase as a function of the host rock type. The abundance of nickel decreases almost exponentially from $4.9 \%$ in peridotites to $0.8 \%$ in quartz diorites in a manner analogous to that of the silicate nickel illustrated in Fig. 1. In this context it should be mentioned that the electron microprobe determination of the abundance of nickel in the sulphide phase of peridotites and olivine gabbros very low in sulphides, gave average values distinctly higher than those reported in Fig. $6(6.9 \% \mathrm{Ni}$ for peridotites and $2.7 \% \mathrm{Ni}$ for olivine gabbros). This is due to the fact that the sulphide phases in some samples were

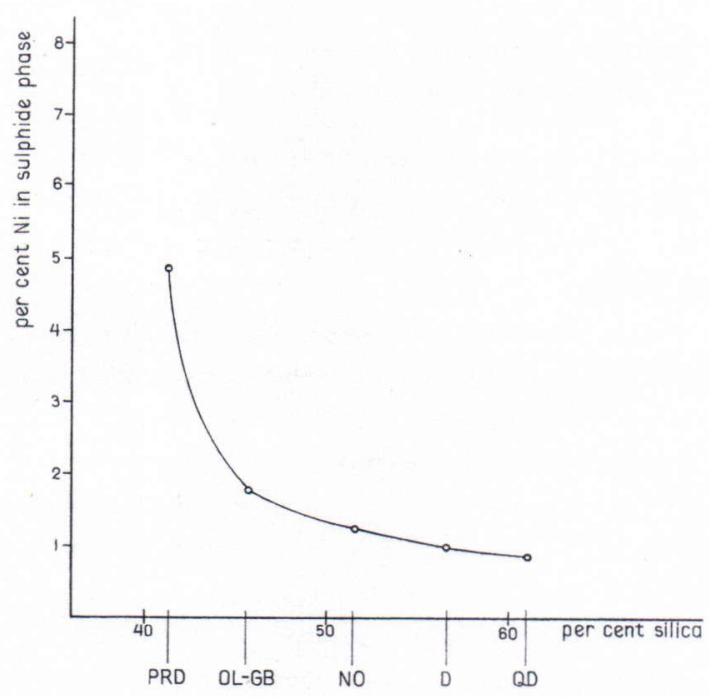

Frg. 6. The average nickel percentage of the sulphide phase as against the silica per cent. PRD = peridotite, $\mathrm{OL}-\mathrm{GB}=$ olivine gabbro, $\mathrm{NO}=$ norite, $\mathrm{D}=$ diorite and $\mathrm{QD}=$ quartz diorite. extreme, i.e. they were composed almost exclusively of pentladite or millerite.

Table 2. lists the new values of the partition coefficients for the distribution of nickel between the sulphide phase and the coexisting mafic silicates: olivine, hypersthene, augite and amphibole. The data are arranged according to rock types to illustrate the influence of the host rock on the numerical values of the partition coefficients. An examination of the table shows that high significant positive correlations exist between the abundances of nickel in the sulphide and silicate phases. The numerical values of the correlaton coefficients generally fluctuate between 0.6 and 0.8 and only three times, probably due to the small number of samples, do the values go below 0.6.

The average numerical values of a particular coefficient of partition vary from one rock type to another. This variation is partly random and statistically non-significant. However, on the whole there is an important and significant trend in the values of the partition coefficients. Thus, the differences in $\mathrm{Sulph}^{\mathrm{Ni}} / \mathrm{Ol}^{\mathrm{Ni}}$ between peridotites and olivine gabbros (55 as against 43) and the $\mathrm{Sulph}^{N i} / \mathrm{Amph}^{N i}$ between peridotites and all the other rock types listed in Table 2 are significant. The differences in the Sulph ${ }^{N i}$ $\mathrm{Amph}^{N i}$ between pyroxene gabbros and amphibole gabbros or quartz diorites are statistically less significant, yet indicative. Also indicative are the differences in the $\mathrm{Sulph}^{\mathrm{Ni}} / \mathrm{Hy}^{\mathrm{Ni}}$ between peridotites and pyroxene gabbros (185 as against 130), olivine gabbros and perknites (185 as against 146) as well as between olivine gabbros and pyroxene gabbros (159 as against 130). Significant differences further exist in the $\mathrm{Sulph}^{N i} / \operatorname{Aug}^{N i}$ between peridotites and olivine gabbros (260 as against 181) and peridotites and amphibole gabbros (260 as against 164). Indicative differences characterize the Sulph ${ }^{N i} / \mathrm{Aug}^{\mathrm{Ni}}$ between olivine gabbros and perknites (181 as against 215) as well as between amphibole gab bros and perknites (164 as against 215). The above implies that the numerical values of the 
TABle 2.

Partition of nickel between sulphide fractions and coexisting mafic silicates in ultrabasic-basic rocks.

\begin{tabular}{|c|c|c|c|c|c|}
\hline Partition & Rock type & K & SD & $\mathrm{R}$ & $\mathrm{N}$ \\
\hline $\begin{array}{l}\operatorname{Sulph}^{N i} / \mathrm{OlNi} \\
{ }^{\prime}\end{array}$ & $\begin{array}{l}\text { Peridotite } \ldots \ldots \ldots \ldots \ldots \ldots \ldots \ldots \\
\text { Olivine gabbro } \ldots \ldots \ldots \ldots \ldots \ldots \ldots\end{array}$ & $\begin{array}{l}55 \\
43 \\
\end{array}$ & $\begin{array}{l}25 \\
19 \\
\end{array}$ & $\begin{array}{l}0.797 \\
0.692 \\
\end{array}$ & $\begin{array}{l}50 \\
34 \\
\end{array}$ \\
\hline $\begin{array}{c}\mathrm{Sulph} N i / \mathrm{Hy}^{N} N_{i} \\
» \\
» \\
» \\
» \\
\end{array}$ & $\begin{array}{l}\text { Peridotite } \ldots \ldots \ldots \ldots \ldots \ldots \ldots \\
\text { Perknite } \ldots \ldots \ldots \ldots \ldots \ldots \\
\text { Olivine gabbro } \ldots \ldots \ldots \ldots \ldots \ldots \\
\text { Pyroxene gabbro } \ldots \ldots \ldots \ldots \\
\text { Amphibole gabbro } \ldots \ldots \ldots \ldots \ldots\end{array}$ & $\begin{array}{l}185 \\
146 \\
159 \\
130 \\
159 \\
\end{array}$ & $\begin{array}{r}93 \\
77 \\
77 \\
86 \\
101 \\
\end{array}$ & $\begin{array}{l}0.587 \\
0.741 \\
0.657 \\
0.790 \\
0.867\end{array}$ & $\begin{array}{r}26 \\
42 \\
41 \\
255 \\
25\end{array}$ \\
\hline $\begin{array}{c}\text { SulphNi} \text { AugNi }^{N i} \\
\text { " } \\
" \\
" \\
" \\
\end{array}$ & $\begin{array}{l}\text { Peridotite } \ldots \ldots \ldots \ldots \ldots \ldots \\
\text { Perknite } \ldots \ldots \ldots \ldots \ldots \\
\text { Olivine gabbro } \ldots \ldots \ldots \ldots \ldots \ldots \\
\text { Pyroxene gabbro } \ldots \ldots \ldots \ldots \\
\text { Amphibole gabbro } \ldots \ldots \ldots \ldots \ldots\end{array}$ & $\begin{array}{l}260 \\
215 \\
181 \\
211 \\
164 \\
\end{array}$ & $\begin{array}{r}124 \\
91 \\
74 \\
409 \\
97 \\
\end{array}$ & $\begin{array}{l}0.753 \\
0.642 \\
0.829 \\
0.652 \\
0.893 \\
\end{array}$ & $\begin{array}{r}19 \\
50 \\
28 \\
159 \\
16\end{array}$ \\
\hline $\begin{array}{c}\text { SulphNi/AmphNi } \\
\text { " } \\
" \\
" \\
" \\
" \\
" \\
"\end{array}$ & $\begin{array}{l}\text { Peridotite } \ldots \ldots \ldots \ldots \ldots \ldots \ldots \\
\text { Perknite } \ldots \ldots \ldots \ldots \ldots \ldots \\
\text { Olivine gabbro } \ldots \ldots \ldots \ldots \ldots \ldots \\
\text { Pyroxene gabbro } \ldots \ldots \ldots \ldots \\
\text { Amphibole gabbro } \ldots \ldots \ldots \ldots \ldots \\
\text { Diorite } \ldots \ldots \ldots \ldots \\
\text { Quartz diorite } \ldots \ldots \ldots \ldots \ldots \ldots\end{array}$ & $\begin{array}{r}156 \\
105 \\
105 \\
105 \\
96 \\
88 \\
90\end{array}$ & $\begin{array}{l}71 \\
53 \\
45 \\
58 \\
47 \\
50 \\
59\end{array}$ & $\begin{array}{l}0.823 \\
0.756 \\
0.523 \\
0.784 \\
0.851 \\
0.426 \\
0.619\end{array}$ & $\begin{array}{r}46 \\
112 \\
11 \\
214 \\
233 \\
13 \\
59\end{array}$ \\
\hline
\end{tabular}

$\mathrm{K}=$ mean partition coefficient

$\mathrm{SD}=$ standard deviation of $\mathrm{K}$

$\mathrm{R}=$ coefficient of correlation

$\mathrm{N}=$ number of determinations

partition coefficients of peridotites significantly differ from those of the rocks with more acid compositions. Indicative differences also exist in some coefficients between gabroic rock types and in such a manner that the numerical values of the coefficients tend to decrease with the increase in the silica percent in the host rocks, i.e. from ultramafic rocks towards more acid variants. Since the temperature of formation decreases in the same direction and is a dominant factor in the crystallisation differentiation, it is well motivated to expect that temperature controlls the partition of nickel between the coexisting phases. The data compiled in Table 2 thus strongly suggest that the thiophile character of nickel increases with increasing temperature and, consequently, at lower temperatures relatively more nickel enters into silicates at the expence of the sulphide phase.

The comparison of the numerical values of the partition coefficients listed in Table 2 with those reported previously by the present author (Häkli, 1963) reveals that the former are often somewhat higher than the older ones. The discrepancy is attributable to two factors at least. First, the earlier determinations were based on samples rich in sulphides, whereas the new values were obtained from speciments with a low sulphur content. This might suggest that the amount of sulphides has an effect on the numerical value of the partition coefficients e.g. by lowering the temperature at which the system »freezes» and attains the final equilibrium. Second, the separated silicates used for the earlier determinations might have contained very small amounts of sulphide inclusions in spite of the acid treatment applied to them, thus giving values too high for the silicate nickel abundances and correspondingly lowering the numerical values for the sulphide-silicate partition coefficients. 


\section{Influence of sulphides on the nickel content of mafic silicates}

The data obtained from various nickel-bearing mineralisations in Finland suggest that the presence of the sulphide phase affects the abundance of nickel in mafic silicates particularly when the abundance of sulphides clearly exceeds the average. In general, the nickel content of silicates decreases parallel to the progress of the crystallisation differentiation and is thus also inversely proportional to the abundance of silicate iron. In the absence of sulphides the abundance of nickel e.g. in olivines may reach values as high as $3000-3500 \mathrm{ppm}$ in the early magmatic and high-temperature differentiates. However, should there be sulphides present to such an extent as to produce even a low-grade mineralisation, then the abundance of nickel in silicates drops considerably. This phenomenon is very prominent e.g. in the Tyrvää nickel deposit in which the nickel mineralisation is associated with a peridotite body and the nickelbearing sulphides occur mainly in its lower parts close to the bottom contact with the adjacent mica schist. In a vertical drill hole (Fig. 7), which

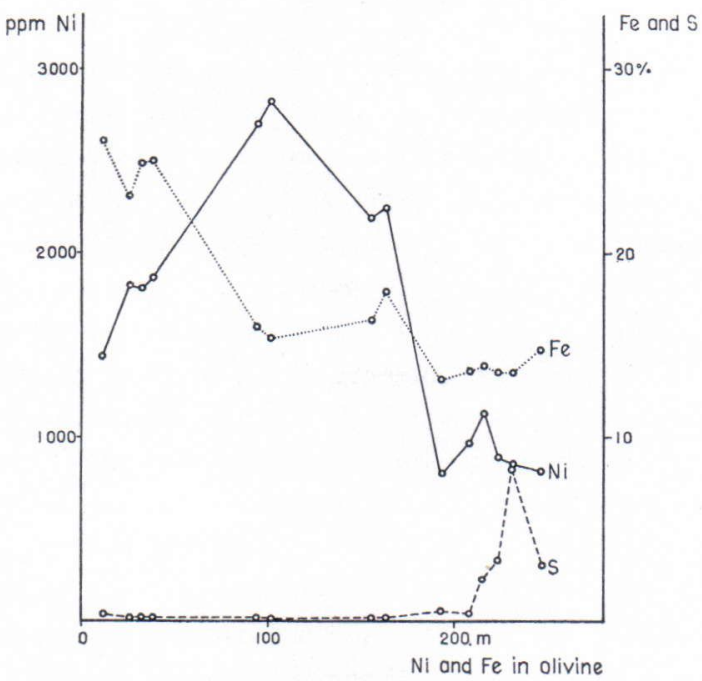

Frg. 7. The sulphur percentage in the host rock and the abundances of nickel and iron in olivine as against the depth. Drill hole 68, Tyrvää. starts in a non-mineralised peridotite and having intersected the mineralised lower contact of the peridotite subsequently penetrates the underlying mica schist, the abundance of nickel in olivines increases steadily from $1450 \mathrm{ppm}$ at the surface to $2800 \mathrm{ppm}$ at a depth of about $100 \mathrm{~m}$. At the same time, the abundance of iron decreases from 26 per cent to 15.5 per cent. From 100 m downwards the abundance of nickel decreases rapidly until in the mineralised lower part of the peridotite it reaches an approximately constant value of about $900 \mathrm{ppm}$. Similar phenomena, though less spectacular, have been observed in the nickel deposits of Kotalahti, Kylmäkoski and Parikkala.

The depletion of the mafic silicates in nickel in the presence of sulphides can be explaned on the basis of sulphurisation (Kullerud and Yoder, 1963, 1964; Naldrett, 1966; Cheney and Lange, 1967) by assuming an external source for sulphur. However, this phenomenon seems to be too common to be attributed entirely to the sulphur from the country rocks. Instead, it is reasonable to assume that comagmatic sulphides could also be responsible for the nickel depletion due to the reactions which take place between mafic silicates and sulphides during the cooling stage of the basic intrusives.

According to Naldrett, Craing and Kullerud (1967) the bulk compositions of most pyrrhotitepentlandite-chalcopyrite deposits are such that the exsolution of pentlandite from the monosulphide solid solution starts at about $500 \mathrm{C}^{\circ}$. Since pentlandite has a lower sulphur to metal ratio than pyrrhotite, pentlandite exsolution from a nickeliferous pyrrhotite solid solution is accompanied by a liberation of sulphur, which either forms pyrite or, at low temperatures (below $300 \mathrm{C}^{\circ}$ ), monoclinic pyrrhotite. However, in an appropriate milieu, instead of producing pyrite, the liberated sulphur may react with mafic nickel-bearing silicates forming pyrrhotite and pentlandite as demonstrated by Kullerud and Yoder (1963, 1964). Due to this reaction, the mafic silicates around and in the sulphide accumulations become depleted particularly in nickel, 
since under these circumstanses it has a higher affinity for sulphur than iron. The phenomenon could thus be attributed to autosulphurisation.

It is apparent from the foregoing that the plot of nickel versus iron in mafic silicates, notably olivines, may suggest the existence of a sulphiderich portion in an intrusive undergoing the exploration by showing that some samples contain silicates in which the abundance of nickel is significantly less than what could be expected on the basis of their iron contents. This naturally implies that the sampling has been carried out in such a manner that rocks within the range of influence of the sulphurisation have been included but it does not imply that the samples necessarily contain sulphur in excess of the average. However, since the nickel depleting action of the sulphides seems to be effective only for a distance of about $100 \mathrm{~m}$ at the most, the explorational applications of this method will seldom be of much practical importance.

\section{Distribution of silicate nickel in mafic intrusives}

The study on the distribution of the abundance of nickel in a particular silicate phase within mafic-ultramafic intrusives reveals, in general, the same characteristics as those obtained by more conventional methods, with the exception, however, that by plotting the variation in the nickel abundance of a phase, features related to the differentiation history of the intrusives may appear which are not readily recognised by other methods. Apart from the homogeneous or only slightly differentiated bodies such as serpentinites or related rocks, the distribution pattern of the silicate nickel in mafic-ultramafic intrusives permits them to be tentatively grouped into two categories:

1. The majority of the intrusives appears to belong to Group I of which it is characteristic that high-temperature differentiates ranging from olivine gabbros to dunite occupy the central parts of the bodies, the rest being rocks of the gabbro-diorite suite. The genetic relation between the hightemperature central core and the enveloping gabbros is not always clear since the contacts between them are seldom exposed. Field evidence suggests that there are circumstances in which the gabbros are older than the more basic rocks but also circumstances in which the opposite holds true. In either case, the juxtaposition of the gabbros and the more mafic rocks seems to indicate that they were derived from a common magma and that they are related to one another, if not in situ, then at a greater depth, for they were clearly emplaced along the same zones of weakness in most cases.

A distinctive feature of these intrusives is that they seem to have crystallised from the centre outwards producing zoned structures, the mode of formation of which is not readily explained. Various hypotheses have been presented in literature to delineate the origin of zoned ultramafic complexes, and the proposals summarised by Taylor (1967) are abviously applicable also to mafic bodies. On the basis of field and geochemical evidence, the present author feels that in most cases the zoned structure of the intrusives of this group is attributable either to flowage differentiation, multiple intrusion or perhaps both.

2. The intrusives of Group II often show stratiform features and apparently originated as superimposed accumulations of crystals which formed during the fractional differentiation of gabbroic magma in situ under tectonically peaceful conditions. Consequently, these massifs have a zone slightly above their bottom contact in which the mafic silicates are considerably enriched in nickel. The possible sulphide accumulations are also situated in this zone. Some of the intrusives of this group are sheet-like and lenticular in shape, some others favour more rounded forms.

The Joutsenmäki-Tolvaniemi gabbro intrusive, near the town of Savonlinna (Gaál and Rauhamäki, 1971; Hackman, 1933), is a typical representative of Group I. Most of the massif 


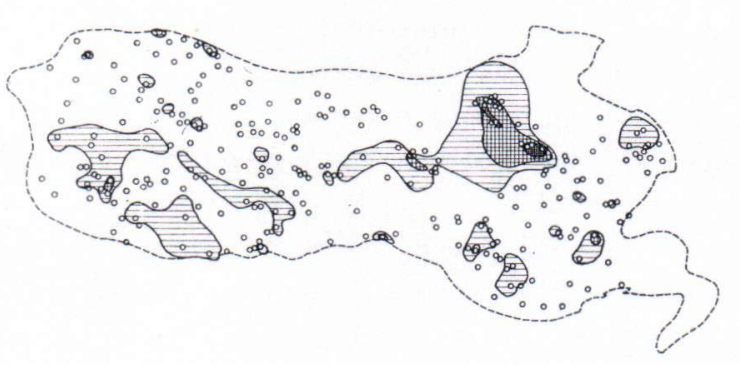

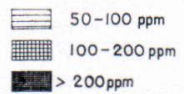

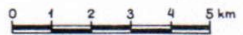

FIG. 8. The distribution of nickel in orthopyroxenes on the surface of the Joutsenmäki-Tolvaniemi gabbro intrusive, NW of Savonlinna. The circles indicate the sample locations.

is composed of rocks ranging from quartz diorite to pyroxene gabbro, but in addition, there are isolated portions of olivine gabbros whose locations are indicated by the areas of higher nickel abundances in Fig. 8. As mentioned previously, the intrusive appears to be produced by at least two magma intrusions with a different nickel abundance in each (see page 253). Consequently, the anomalies of the high nickel abundances largely coincide with the locations of the olivine gabbros of the nickel-rich type. These occur as scattered bodies all over the intrusive.

The tectonic studies in the Haukivesi area (Gaál and Rauhamäki, 1971) suggest that the western part of the massif may represent the horizontal section of a vertical pipe which acted as a feeding channel for the rising gabbroic magmas.

An illustrative case of the intrusives of Group II is the Porttivaara gabbro body in Taivalkoski (Ohenoja, 1968). This lenticular intrusive, which is about $30 \mathrm{kms}$ long and $4 \mathrm{kms}$ wide, has a moderate northward dip. (Fig. 9). The hightemperature nickel-rich rocks occur along the bottom contact of the massif at its southern contact. The anomalous nickel abundances are met with in a roughly $24 \mathrm{~km}$ long zone, which persistently follows the early differentiates of the intrusive. Approximately in the middle of the zone the nickel abundances reach their highest values, which e.g. in amphiboles locally exceed 2000 ppm Ni. From here the abundances gradually decrease towards the ends. Gravitative differentiation has produced a low-grade sulphide mineralisation at the bottom contact of the intrusive, along which it has been traced for several kilometres.

Explorational activities performed on various basic intrusives indicate that those of the second group seem to have a higher probability of being a host rock for an economic nickel deposit than the intrusives of the first group. However, it should be kept in mind that the section provided by the present land surface may expose only one rock type thus making the intrusive appear as a nondifferentiated or only slightly differentiated one. Or then only rocks of gabbroic composition are exposed, which makes it a crucial question as to whether or not the intrusive also includes ultramafic differentiates in its hidden parts which should be explored for possible nickel ores. For the final explorational evalution of each intrusive it is thus necessary to gather from them as much information as possible with different methods to avoid the drawing of erroneous and premature conclusions.
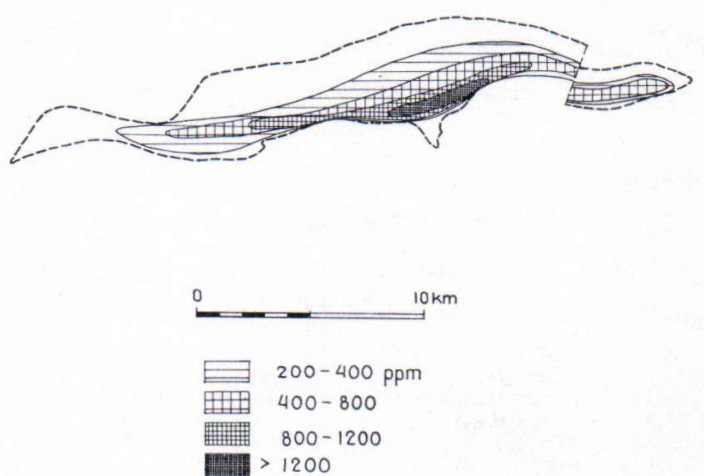

FIG. 9. The distribution of nickel in amphiboles on the surface of the Porttivaara gabbro intrusive in Taivalkoski. 


\section{Areal distribution of $\mathrm{Ni}$-indicative mafic-ultramafic rocks}

The economic value of a sulphide nickel deposit relies, among other things, on the tonnage of nickel incorporated in the sulphides. This then obviously depends on the amount of sulphide phase present and on the nickel percentage in it. Consequently, the examination of the areal distribution of the percentage of nickel in the sulphide phase and the amount of sulphide

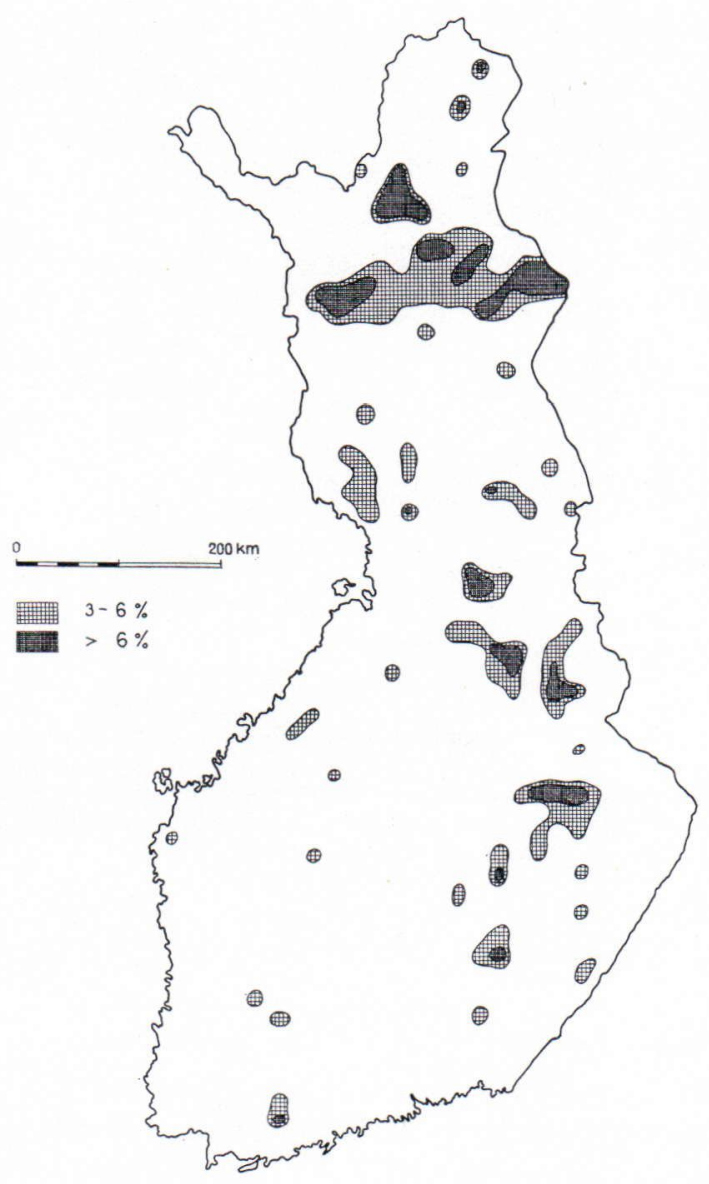

FIG. 10. The distribution of the average nickel abundances in the sulphide phases of the Finnish mafic-ultramafic rocks. The nickel percentage in the sulphide phase of each sample was estimated by multiplying the nickel abundances in mafic silicates by the values of the distribution coefficients listed in Table 2. nickel in mafic-ultramafic rocks gives useful information concerning the areas favourable to the occurrence of possible nickel deposits.

The distribution of the average nickel percentages in the sulphide phases of the Finnish mafic-ultramafic rocks is illustrated in Fig. 10. The map was made by superimposing a $20 \times 20$ $\mathrm{km}$ grid over the map of Finland and computing the averages of all the samples falling within each grid.

Essentially Fig. 10 indicates the areal distribution of ultramafic rocks or rather the areas in which the ultramafic rocks predominate over the mafic and thus less nickel-rich rocks. The zones favourable for the occurrence of nickel deposits and running across the country in NW-SE and W-E directions (see Fig. 12.) are not indicated on the map at all due to the fact that in these zones numerous mafic rocks with low Ni-percentages in the sulphide phase abound making the averages low and concealing the indicative intrusions. This hindrance is avoided if, instead of the averages, the locations of those samples in which the Ni-percentage exceeds a certain limit, say $3 \%$, are plotted on the map (Fig. 11). A closer examination of Fig. 11 shows that the ultramafic rocks with a high Ni-percentage in the sulphide phase are still well represented on the map but that, in addition to them, distinct zones appear in the schist area of central and SW Finland which are of importance for the exploration of nickel in this country. Two main zones are discernible. One trends NW-SE and runs from Nivala to Parikkala and obviously extends in both directions beyond these places. The other zone can be traced between Pori and Kylmäkoski but may continue in eastwards as far as Taipalsaari. Apart from these two zones there seems to be a weakly developed zone bisecting the former. From about Imatra it trends NWW for approximately $200 \mathrm{~km}$. Almost perpendicular to it there is still a zone trending NE parallel to and nearly in the extension of the Outokumpu formation. As a whole the distribution pattern of the indicative sample locations 


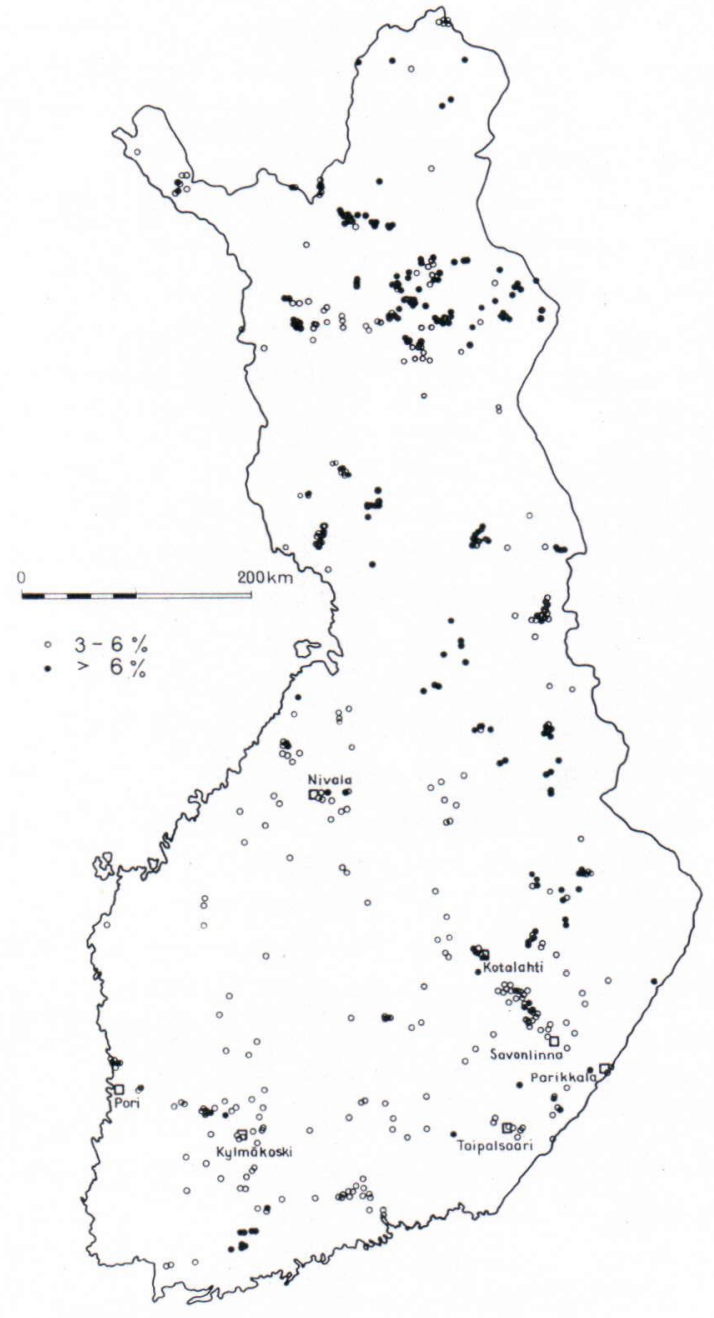

FIG. 11. The locations of the mafic-ultramafic samples samples with the nickel percentage in the sulphide phase exceeding $3 \%$.

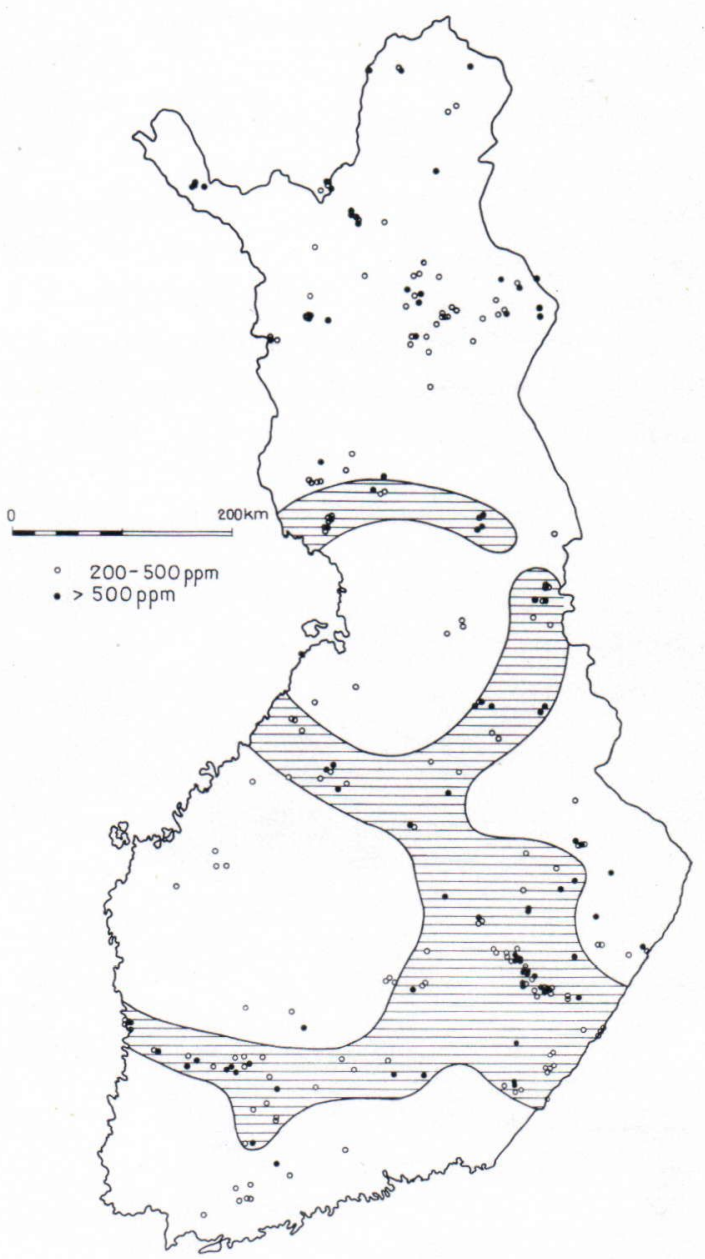

FIG. 12. The locations of mafic-ultramafic samples with sulphide nickel exceeding $200 \mathrm{ppm}$. The shaded area indicates the zones within which fall most of the nickel showings discovered so far by the Exploration Department of the Outokumpu Co.

mated by multiplying the nickel contents of the mafic silicates by the partition coefficients listed in Table 2. The map in Fig. 12 does not differ much from that in the previous figure but delineates the zones illustrated in Fig. 11 perhaps even more clearly than the latter, especially as far as the Nivala-Parikkala and Pori-Kylmäkoski zones are concerned.

The areal distribution of the sample locations coincides well with the shaded areas on the map. the analytical data for sulphur and the Ni-percentage in the sulphide phase. The latter was esti- much resemble that of the Ni-factor scores eported by Häkli (1970). sulphide nickel exceeds $200 \mathrm{ppm}$. The abundance of sulphide nickel was computed on the basis of 
These areas include most of the nickel showings detected by the Exploration Department of the Outokumpu Company up until 1969. A positive and significant correlation exists between the areal distribution of the nickel showings on the one hand and the distribution of the rocks with a high Ni-percentage in the sulphide phase or with high sulphide nickel on the other. This holds true to a considerable extent also for the nickel showings in North Kaleria which are associated with the Outokumpu type of $\mathrm{Cu}$ mineralisations (Huhma and Huhma, 1970) and which occur either in skarns or in serpentinites and quartz rocks in the immediate vicinity of the former.

Lapland is a striking exception to the above rule. The mafic-ultramafic rocks in Lapland have high nickel percentages in the sulphide phase and many of them also have moderate abundances of sulphide nickel. Nevertheless, only a few promising nickel showings have been found in Lapland so tar.

The analytical data obtained from the specimens of the Ni-programme suggest that on an averge the mafic-ultramafic rocks in Lapland contain somewhat less sulphur than the corresponding rocks in the rest of the country $(0.1 \%$ $\mathrm{S}$ as against $0.14 \% \mathrm{~S}$ ). However, it is doubtful whether this difference alone could account for the lack of nickel showings. In the light of experience gathered in other parts of country it may not be too optimistic to anticipate that increased explorational activities will sooner or later uncover nickel deposits also in Lapland.

At the present time only limited information is available concerning the internal structure and development of the nickel-favourable zones and the mode of occurrence of the promising maficultramafic bodies in them. However, a comprehesive geologic and tectonic mapping in some of the key areas of the Nivala-Parikkala zone carried out by Gaál and his coworkers (Gaál and Rauhamäki, 1971) has revealed that the samples with a high nickel percentage in the sulphide phase or with a high abundance of sulphide nickel originate from the basic intrusives whose emplacement and mode of occurrence were controlled by a complicated folding-, shearing- and faulting mechanism.

In the Haukivesi area, between Varkaus and Savonlinna, the fracture zone manifests itself as a set of lineaments of which two dominant ones are those of Haukivesi and Härmäniemi. These faults are components of a wider shear zone which apparently has been active since the earliest geosynclinal stage of the area. The deformation of the rocks in the zone took place in fouth phases, the second one giving rise to the synkinematic mafic intrusives to which the host rocks of the nickel showings also belong.

Further north, in the Kotalahti area, the elongation of the basic bodies in N-S direction suggest that the emplacement of these massifs was controlled by tension openings produced by the forces acting parallel to the strike of the Nivala-Parikkala zone, obviously contemporaneously with the uprising of the related basic magmas in the Haukivesi area.

\section{Summary and conclusions}

The conclusions of this study may be summarised briefly as follows:

(1) The abundance of nickel in mafic silicates decreases approximately exponentially from ultramafic rocks to more acid rocks as the silica content increases. Within each rock type there is a large variation in the nickel abundances in silicates and the frequency distributions also vary in accordance with the rock types. In ultramafic rocks and olivine gabbros the distributions are almost normal but in the more silicic rocks the distributions approach lognormal or gamma types. Two groups of ultramafic rocks have been established in relation to the abundance of nickel in mafic silicates. The predomnant nickel-rich type evidently derives from basaltic magmas, whereas the nickel-poor type obviously represents ultramafic fasies of granodiorite or related bodies. The economic nickel deposits 
seem to be invariably associated with the rocks of the nickel-rich type.

(2) The partition of nickel between co-crystallised mafic silicates appears to be dependent on the rock type and, thus, on the physical conditions, notably temperature, prevailing during crystallisation. Apart from throwing light on the cooling history of mafic-ultramafic complexes, the model temperature estimates based on $\mathrm{Ol}^{N i} / \mathrm{Aug}^{\mathrm{Ni}}$ partition have turned out to be of practical explorational value making the comparison of different basic bodies in relation to their nickel abundances sound and meaningfu].

(3) Positive and significant correlations exist between the nickel percentage in the sulphide phase and the abundance of nickel in coexisting mafic silicates. On the basis of the appropriate partition coefficients and the nickel abundances in silicates, the nickel content of the sulphide phase can be evaluated without a direct determination. In cases of a low sulphur content the latter could be troublesome due to the analytical difficulties arising from the solubility of the nickel of some of the silicates in acids. The almost exponential dependence of the nickel percentage of the sulphide phase on the silica per cent of the host rock permits the estimation of the nickel percentage $e . g$. in the sulphide phase of the hidden ultramafic rocks in a complex whose mafic differentiates are accessible and can be submitted to analysis.

(4) In several nickel deposits the sulphides have been observed to have extracted some nickel and perhap also iron from mafic silicates. This phenomenon can be attributed to sulphurisation caused by external sulphur especially when sulphide-rich black schists are nearby. However, the liberation of sulphur when the monosulphide phase turns into pyrrhotite, pentlandite and chalcopyrite during the cooling may also give rise to reactions between silicates and sulphur through which the mafic silicates lose some of their nickel to form nickel-bearing sulphides. The depletion of mafic silicates in nickel within the range of influence of sulphides may thus also be caủsè by comangmatic sulphides through the action of autosulphurisation.

(5) The distribution patterns of the nickel abundances in the silicates of mafic-ultramafic bodies suggest that in regard to their mode of formation these bodies can be divided into two groups. The intrusives of Group I exhibit a zoned structure, according to which the highest nickel abundances and, thus, the high-temperature rocks occur in the centre of the complex, from which outwards the abundances of nickel decrease. The bodies of Group II are stratiform or at least strongly differentiated intrusives in which the high nickel abundances form a zone along the bottom contact of the complex. Experience gathered so far indicates that the intrusives of Group II have a higher probability of being the host rock of a nickel deposit than do the intrusives of Group I.

(6) The plot on a map of the locations of the samples with a high nickel percentage in the sulphide phase or with a high abundance of sulphide nickel provide the decision-makers of strategic nickel prospecting with useful information. The distribution of points on the map reveals the zones of faults or fractures which controlled the emplacement of mafic bodies favourable for the occurrence of possible nickel deposits. Explorational activities should be directed with all vigour into these zones.

Acknowledgments - The author is indebted to the Outokumpu Company for permission to publish this paper. Dr. Paavo Haapala, the chief geologist of the Outokumpu Co., has shown keen interest in the nickel programme from the very beginning and greatly contributed to its progress with many suggestions and fruitful critisism. Dr. V. O. Vähätalo, the former Head of the Exploration Department as well as the present Director Mr. P. Isoangas have generously supported the work in all stages.

A considerable part of the geological staff of the Exploration Department was involved in the collection of the samples. In particular, the aid given by Drs. $H$. Wennervirta, P. Rouhunkoski and. Gaál as well as by Messrs. E. Viluksela, O. Inkinen, R. Himmi, A. Warma, J. Saastamoinen, E. Pehkonen, K. Vormisto an L. Grundström was crucial for the realisation of the investigation. 
Mrs. Pirjo Liimatainen and Mrs. Marja Rannela performed the tedious electron microprobe determinations and Mr. V. Suokonautio made the computer programs needed for the data processing. To all the above persons the author whishes to express his sincere thanks.

\section{REFERENCES}

Cheney, Eric S. and Lange, Ian M. (1967). Evidence for sulfurization and the origin of some Sudbury-type ores. Mineral Deposita 2, pp. 80-94.

Evans, Bernard W. (1969). The nickel partition geothermometer applied to the prehistoric Makaopuhi Lava Lake, Hawaii. Geochim. Cosmochim. Acta 33 p. $409-411$.

Frosterus, BenJ. (1902). Geologisk öfversiktskarta öfver Finland. Sektionen C2 S:t Michel. Geol. Komm. pp. $34-35$.

GaÁl, G. and Rauhamäki, E. (1971). Petrological and structural analysis of the Haukivesi area between Varkaus and Savonlinna, Finland. Bull. geol. Soc. Finland 43, pp. $265-337$.

HaApala, P. S. (1969). Fennoscandian nickel deposits. Econ. Geol. Monograph No 4, pp. 262-275.

Hackman, V. (1933). Suomen geologinen yleiskartta. Savonlinna, p. 124.

Huhma, Aarto and Huhma, Marja (1970). Contribution to the geology and geochemistry of the Outokumpu region. Bull. geol. soc. Finland, 42, pp. 57-88.

HäKlI, Aulrs (1963). Distribution of nickel between the silicate and sulphide phases in some basic intrusions in Finland. Bull. comm. geol. Finlande. No 209.

HäkLI, T. A. (1968). An attempt to apply the Makaopuhi nickel fractionation data to the temperature determination of a basic intrusive. Geochim. Cosmochim. Acta 32. pp. 449-460.

- (1970). Factor analysis of the sulphide phase in maficultramafic rocks in Finland. Bull. geol. soc. Finland. 42, pp. $109-118$.
Kullerud, G. and Yoder, H. S., JR., (1963). Sulphidesilicate relations. Annual rept. of director of geophys. lab. pp. $215-218$.

- (1964). Sulphide-silicate relations. Annual rept. of director of geophys. lab. pp. 218-222.

Miкkola, Erkki (1941). Suomen geologinen yleiskartta. Muonio-Sodankylä-Tuntsajoki. Suomen geologinen toimikunta, p. 63.

NALDRETT, A. J. (1966). The role of sulphurization in the genesis of iron-nickel sulphide deposits of the Porcupine district, Ontario. Canadian Min. and Met. bll. pp. $1-9$.

Oertel, A. C. (1969). Frequency distributions of element concentrations. I Theoretical aspects. Geochim. Cosmochim. Acta 33, pp. 821-831.

Ohenoja, Vilho (1968). Porttivaaran-Kuusijärven alueen kallioperä. Unpublished thesis. The manuscript in the arch. of the University of Oulu.

Papunen, Heik ki (1971). Sulfide mineralogy of the Kotalahti and Hitura nickel-copper ores, Finland. Ann. Acad. Sci. Fennicae. Vol. 109, pp. 1-74.

Srmkin, Tom (1967). Flow differentiation in the picritic sills of North Skye. Ultramafic and related rocks. Wyllie Peter J. editor. John Wiley \& Sons Inc. pp. 64-69.

- and Sмrтн, J. V. (1970). Minor-element distribution in olivine. Journal of Geol. Vol. 78, pp. 304-325.

TAYlor, Hugh P. JR. (1967). The zoned ultramafic omplexes of southeastern Alaska. Ultramafic and related rocks. John Wiley \& Sons Inc. pp. 97-121. 